\title{
Avaliação dos hábitos de exposição ao sol e de fotoproteção dos universitários da Região Metropolitana de Porto Alegre, $\mathrm{RS}^{*}$ Evaluation of solar exposure and sun-protection behaviors among university students in the Metropolitan Region of Porto Alegre, Brazil*
}

Francine Batista Costa $^{1}$

Magda Blessman Weber ${ }^{2}$

Resumo: FundAMENTOS - Sabe-se que a mudança de hábito da população mundial com relação à exposição ao sol provocou aumento da incidência de câncer da pele nas últimas décadas. Tais informações são especialmente relevantes na Região Sul, na qual há maior prevalência da população branca, mais propensa aos danos solares, em comparação ao restante do Brasil. OвJEtivos - Avaliar os hábitos de exposição ao sol e de fotoproteção dos universitários da Região Metropolitana de Porto Alegre no período de julho a setembro de 2001.

Métodos - Foram respondidos 1.030 questionários por universitários residentes na Região Metropolitana de Porto Alegre.

Resultados - Nos finais de semana, 38,4\% dos estudantes permanecem ao sol entre duas e seis horas diárias. Durante o verão, $43,7 \%$ deles se expõem ao sol entre as 10 e as $15 \mathrm{~h} ; 85 \%$ dos estudantes afirmam usar filtro solar, mas $65 \%$ não o usam ao praticar esportes ao ar livre.

CONCLUSÕES - Os autores observaram que a maioria dos universitários se expõe excessivamente ao sol, em horários impróprios e sem efetiva proteção solar.

Palavras-chave: estudantes; protetores de raios solares.

Summary: BACKGROUND - It is known that changes in the habits of the world population with regard to solar exposure, have caused an increased rate of skin cancer in the last few decades. This information is especially relevant in the Southern region of Brazil, due to the higher prevalence of Caucasians, who are more vulnerable to harm from the sun, compared to other darker skinned Brazilians.

OBJECTIVES - To evaluate the habits of solar exposure and sun-protection among university students in the Metropolitan Region of Porto Alegre, from July to September 2001.

METHODS - 1030 questionnaires were answered by university students living in the Metropolitan Region of Porto Alegre.

RESULTS - On weekends, 38.4\% of the students expose themselves to the sun for 2 to 6 bours daily. During the summer, $43.7 \%$ expose themselves to the sun between 10 am and 3 pm. Eighty-five per cent of the students affirmed that they use sunscreen, but $65 \%$ do not use it when practicing outdoor sports.

CONCLUSIONS - We observed that most university students expose themselves excessively to the sun at inappropriate times of the day and without effective protection against the sun.

Keywords: students; sunscreening agents.

Recebido em 09.06.2003. / Received in June, $09^{\text {hh }}$ of 2003.

Aprovado pelo Conselho Consultivo e aceito para publicação em 16.10.2003. I Approved by the Consultive Council and accepted for publication in October, $16^{\text {th }}$ of 2003.

* Trabalho realizado na Universidade Luterana do Brasil. / Work done at "Universidade Luterana do Brasil".

Médica formada pela Universidade Luterana do Brasil - Ulbra. / M.D., Graduated from Lutheran University of Brazil - Ulbra.

${ }^{2}$ Professora Adjunta Mestre em Dermatologia do Curso de Medicina da Universidade Luterana do Brasil - Ulbra. / Masters degree and Adjunct Professor of Dermatology, Medical course, Lutheran University of Brazil - Ulbra.

C2004 by Anais Brasileiros de Dermatologia 


\section{INTRODUÇÃO}

O câncer de pele é um grave problema de saúde pública devido ao aumento em sua incidência no século $20,{ }^{1,2,3}$ provocado principalmente pelas mudanças de hábito da população mundial com relação à exposição solar. ${ }^{4,5,6}$ No período de 1973 a 1994, a incidência do câncer de pele do tipo melanoma aumentou em $120,5 \%$, e a taxa de mortalidade, para 38,9\%. ${ }^{2}$ Nos Estados Unidos, o risco de desenvolver melanoma foi de um para 1.500, em 1935; um para 250, em 1980; e um para 74, em 2000. , $^{23}$

Nas últimas décadas ampliou-se o conhecimento referente à etiologia do câncer de pele e identificou-se a radiação ultravioleta como um dos principais agentes envolvidos. ${ }^{1,5,7,8,9}$ A maior fonte natural de radiação ultravioleta é o sol, ao qual a pele está em constante exposição, seja durante atividades recreativas ou trabalho. Atualmente, fontes artificiais de radiação ultravioleta são usadas com fins terapêuticos ou estéticos. 1,3,10,11

A prevenção do câncer de pele, no adolescente e no adulto jovem, é importante por ser nessa faixa etária que os indivíduos permanecem grande parte do tempo ao ar livre. ${ }^{13,14}$ Grandes esforços estão sendo empreendidos para melhorar o comportamento das crianças em relação à exposição solar, ${ }^{1,15}$ mas poucos programas de prevenção do câncer de pele são dirigidos aos adolescentes. ${ }^{12,16}$

Apesar de essas campanhas de prevenção darem ênfase aos riscos da exposição solar, os dados da literatura demonstram que $50 \%$ dos adolescentes bronzeiam-se intencionalmente $^{13} \mathrm{e}$, quando ao sol, pouco aplicam o filtro solar ou usam chapéu e camisa, ficando assim expostos excessivamente à radiação durante o verão. ${ }^{12,13,14}$ Bakos et al., em 1994-1995, na Praia de Torres, no Rio Grande do Sul, demonstraram que $36,9 \%$ de uma população com média de idade de 20 anos usavam filtro solar. ${ }^{4}$

A influência da moda e da indústria de cosméticos pode influenciar a percepção dos jovens a respeito dos riscos da exposição solar desprotegida e excessiva., ${ }^{9,12,14,17}$ É importante educar os jovens, e isso deveria começar pelo modelo parental de proteção solar desde a infância. ${ }^{8,12,14,18-21}$

$\mathrm{O}$ uso de filtro solar é uma estratégia efetiva $\mathrm{a}^{10,22,23,24}$ para reduzir a quantidade de radiação ultravioleta e queimadura solar, e também são necessários o uso de outros meios físicos de fotoproteção e o cuidado com relação ao horário de exposição ao sol para diminuir a incidência de câncer de pele..$^{10,11,19,25}$ A identificação do indivíduo de alto risco é importante para o desenvolvimento de esforços de prevenção eficiente. . $^{6,8,11,12,18,26}$

A fim de implementar estratégias de prevenção efetivas, todos os profissionais da área da saúde têm que entender os fatores que afetam a decisão do paciente de se bronzear, bem como devem tentar modificar as percepções públicas para diminuir a exposição solar. 1,67,7,27,28,29 $^{-1}$

Este trabalho propõe-se a avaliar os hábitos de exposição e de proteção solar dos universitários da Região Metropolitana de Porto Alegre. Os resultados da pesquisa

\section{INTRODUCTION}

Skin cancer has become a serious public health problem due to the increase in its incidence during the 20 th century, ${ }^{1,2,3}$ caused mainly by changes in the behavior of the world population regarding solar exposure. ${ }^{4,5,6}$ From 1973 to 1994, the incidence of melanoma type skin cancer increased by $120.5 \%$ and its mortality rate by $38.9 \%{ }^{2}$ In the United States, the risk of developing melanoma rose from 1:500, in 1935; to 1:250, in 1980; and $1: 74$, in $20000^{2,3}$

In recent decades, much knowledge has been acquired regarding the etiology of skin cancer, and ultraviolet radiation has been identified as one of the main agents involved. ${ }^{1,5,7,8,9}$ The greatest natural source of ultraviolet radiation is the sun, to which the skin is in constant exposure, whether during recreational activities or at work. Nowadays, artificial sources of ultraviolet radiation are used for therapeutic or esthetic purposes. ${ }^{1,3,10,11}$

The prevention of skin cancer, among adolescents and young adults, is important since this age group tends to spend the greatest part of their time outdoors. ${ }^{13,14}$ Major efforts are being made to modify children's behavior in relation to solar exposure, ${ }^{1,15}$ but few programs for the prevention of skin cancer are directed to adolescents. ${ }^{12,16}$

Although these prevention campaigns emphasize the risks of solar exposure, data in the literature demonstrates that $50 \%$ of the adolescents become tanned intentionally ${ }^{13}$ and, when in the sun, few apply sunscreen or use a hat and shirt, thereby exposing themselves excessively to radiation during summer. ${ }^{12,13,14}$ Bakos et al., during 1994 -1995, in the coastal city of Praia de Torres, Rio Grande do Sul, demonstrated that $36.9 \%$ of a population with a mean age of 20 years used sunscreen. ${ }^{4}$

The influence of fashion and the cosmetics industry has influenced the perception of the younger generation regarding the risks of unprotected and excessive solar exposure. ${ }^{9,12,14,17}$ It is important to educate the young, and this should begin with a parental model of solar protection from infancy. ${ }^{8,12,14,18-21}$

Use of sunscreen is an effective strategy ${ }^{10,22,23,24}$ to reduce the amount of ultraviolet radiation and sunburn, but other physical means of sun-protection and care regarding the time of exposure to the sun are also necessary to reduce the incidence of skin cancer. ${ }^{10,11,19,25}$ Identification of those individuals at highest risk is important for the development of efficient prevention programs. ${ }^{6,8,11,12,18,26}$

In order to implement effective prevention strategies, all the professionals in the health area have to understand the factors that affect the patients' decision to sunbathe, as well as to try to modify the public perceptions to reduce solar exposure. ${ }^{1,6,7,8,27,28,29}$

The objective of this work was to evaluate the habits regarding solar exposure and use of sunscreen of the university students' of the Metropolitan Region of Porto 
poderão oferecer subsídios para estratégias de prevenção do câncer de pele.

\section{MATERIAL E MÉTODOS}

Foi distribuído um questionário para estudantes universitários da Região Metropolitana da cidade de Porto Alegre, RS. O estudo foi conduzido durante o período de julho a setembro de 2001. Os questionários foram distribuídos em série, pelos pesquisadores, a 1.200 estudantes de cinco universidades da região durante os intervalos das atividades em sala de aula nos períodos diurno e noturno. $\mathrm{O}$ objetivo e a importância da pesquisa constavam no cabeçalho do questionário e foram apresentados aos estudantes no momento da solicitação de participação no estudo. Foram respondidos 1.030 questionários. Não foi levada em consideração a área de graduação do universitário.

O questionário foi elaborado pelos pesquisadores autores deste trabalho e é composto de 10 perguntas, incluindo idade, sexo e questões gerais sobre comportamento e hábito relativos à exposição ao sol, como: 1. tempo e horários de exposição; 2. uso de proteção solar; 3. fator de proteção solar que usa; 4. estação do ano em que usa filtro solar; 5. Uso de outros meios físicos de proteção solar; e 6. uso de filtro solar durante a prática de esportes ao ar livre.

Os dados foram reunidos no programa SPSS (Statistical Package for Social Sciences), e sua análise estatística foi realizada de forma descritiva com utilização de freqüências absolutas (n) e relativas (\%).

\section{RESULTADOS}

Foram respondidos 1.030 questionários. A amostra foi composta por 343 universitários do sexo masculino $(33,3 \%)$ e 687 do sexo feminino $(66,7 \%)$, com média de idade de 22,7 $( \pm 5,4)$ anos (Quadro 1).

Quanto ao período de exposição solar, foram encontrados os seguintes resultados: $70,7 \%$ dos estudantes expõem-se ao sol no máximo até duas horas diárias durante a semana (de segunda a sexta-feira). No final de semana, $4,9 \%$ dos estudantes expõem-se ao sol por mais de seis horas diárias, e 38,4\% expõem-se entre duas e seis horas diárias. O horário de exposição ao sol mais freqüiente durante o verão é após as $15 \mathrm{~h}$ ( $70,6 \%$ dos estudantes), sendo que desses indivíduos $43,7 \%$ também se expõem entre as 10 e as $15 \mathrm{~h}$ (Quadro 1).

Quanto à proteção solar, foram encontrados os seguintes resultados: $85,2 \%$ da amostra usa filtro solar. Desses, $84,9 \%$ escolhem fator de proteção solar maior do que oito, $65 \%$ não o usam quando praticam esportes ao ar livre, e 17,9\% o aplicam durante todas as estações do ano. O uso de outros meios físicos para fotoproteção apresenta a seguinte freqüência: $42 \%$ dos estudantes usam camiseta, 34,8\%, chapéu, e 38,4\%, guarda-sol (Quadro 2).

Dos pesquisados que afirmam não fazer uso de filtro solar, a maioria é do sexo masculino (62,5\%), menor de 25 anos $(84,9 \%)$ e não usa outros meios de proteção solar,
Alegre. The results of the research provide guidance for strategies to prevent skin cancer.

\section{MATERIAL AND METHODS}

A questionnaire was distributed among university students of the Metropolitan Region of Porto Alegre, State of Rio Grande do Sul. The study was conducted from July to September, 2001. The questionnaires were distributed in series, by the researchers, to 1,200 students of five universities during the intervals between classroom activities during the day and evening classes. The objective and the importance of the research was stated at the top of the questionnaires and these were presented to the students at the moment they were requested to participate in the study. A total of 1,030 questionnaires were completed. The subject area in which the university students were graduating was not taken into consideration.

The questionnaire was prepared by the authors of the present work and comprised 10 questions, including age, sex and general questions on behavior and relative to solar exposure, such as: 1. duration and time of exposure; 2. use of sunscreen; 3. solar protection factor used; 4. season in which sunscreen is used; 5. use of other physical means of solar protection; and 6. use of sunscreen during outdoor sports.

The data were collected in the program SPSS (Statistical Package for Social Sciences), and statistical analysis was performed in a descriptive manner using absolute (n) and relative (\%) frequencies.

\section{RESULTS}

A total of 1,030 questionnaires were completed. The sample was composed of 343 male (33.3\%) and 687 female (66.7\%) students, with a mean age of 22.7 years $( \pm 5.4)$ (Chart 1).

As for the period of solar exposure, the following results were found: $70.7 \%$ of the students were exposed to the sun for a maximum of up to two hours per day during the week (Monday to Friday). At the weekend, 4.9\% of the students exposed themselves to the sun for more than six hours a day, and 38.4\% exposed themselves for between two to six hours a day. The most frequent time for solar exposure during the summer was after 15:00 (70.6\% of the students), and of these individuals, 43.7\% also exposed themselves between 10:00 and 15:00 (Chart 1).

As for solar protection, the following results were found: $85.2 \%$ of the sample use sunscreen. Of these, $84.9 \%$ choose a sun protection factor over eight, $65 \%$ do not use it during outdoor sports, and 17.9\% apply it during all the seasons of the year. The use of other physical means for solar protection presented the following frequency: shirts (42\%), hats (34.8\%), and beach umbrella (38.4\%) (Chart 2).

Of the participants that affirmed they do not use sunscreen, most were male (62.5\%) and under 25 years of age $(84.9 \%)$, besides not using other means of solar protection, 
Quadro 1: Número e percentual de universitários da região metropolitana de Porto Alegre em 2001 segundo características da amostra quanto a sexo, idade e hábitos de exposição solar / Chart 1: Number and percentage of university students in the metropolitan region of Porto Alegre in 2001, according to characteristics of the sample in terms of age, sex and solar exposure behaviors

\begin{tabular}{|c|c|c|c|}
\hline & & N. & $\%$ \\
\hline \multirow[t]{2}{*}{ Sexo / Sex } & Masculino / Male & 343 & 33.3 \\
\hline & Feminino / Female & 687 & 66.7 \\
\hline \multirow[t]{3}{*}{ Faixa etária* / Age group* } & Até 20 anos / Up to 20 years & 422 & 41 \\
\hline & 21 a 25 anos / 21 to 25 years & 445 & 43.2 \\
\hline & Mais de 26 anos / Over 26 years & 163 & 15.8 \\
\hline Exposição solar diária de segunda a sexta-feira & Até duas horas / Up to 2 hours & 728 & 70.7 \\
\hline \multirow{2}{*}{ Solar exposure during weekdays } & De duas até seis horas / 2 to 6 hours & 282 & 27.4 \\
\hline & Mais de seis horas / Over six hours & 20 & 1.9 \\
\hline Exposição solar diária no final de semana & Até duas horas / Up to 2 hours & 584 & 56.7 \\
\hline \multirow[t]{2}{*}{ Solar exposure during weekend } & De duas até seis horas / 2 to 6 hours & 396 & 38.4 \\
\hline & Mais de seis horas / Over six hours & 50 & 4.9 \\
\hline & Até 10h / Before 10:00h & 423 & 41.1 \\
\hline \multirow[t]{2}{*}{ Time of solar exposure during summer ** } & Entre 10 e $15 \mathrm{~h} /$ Between 10:00 to $15: 00 \mathrm{~h}$ & 450 & 43.7 \\
\hline & Após 15h / After 15:00h & 727 & 70.6 \\
\hline
\end{tabular}

$\mathrm{n}$ : freqüência da amostra / frequency of sample

$\%$ : porcentagem / percentage

* média de idade: $22,7( \pm 5,4)$ anos / mean age: $22.7( \pm 5.4)$ years

** alternativas de múltipla escolha / multiple choice questions

como chapéu $(55,9 \%)$, camiseta $(45,4 \%)$ e guarda-sol $(85,5 \%)$ (Quadro 3).

\section{DISCUSSÃO}

No presente trabalho, os universitários foram questionados quanto à exposição usual ao sol e ao freqüente uso de fotoproteção. Os resultados, no que se refere ao tempo de exposição ao sol e ao uso de meios físicos de proteção solar, são semelhantes aos dados da literatura. ${ }^{8,101,22,28}$

Setenta por cento dos estudantes expõem-se em horário de menor risco para a pele, após as $15 \mathrm{~h}$. Porém, 43,7\% dos estudantes também se expõem no horário de maior intensidade de radiação ultravioleta, entre 10 e $15 \mathrm{~h}$. A literatura justifica esse comportamento, durante o verão, devido a fatores sociais, como almoçar tarde; fazer mais esportes ao ar livre; a intenção de aproveitar as férias. ${ }^{4}$ Dessa forma, as atividades ao ar livre ocorrem principalmente em horários impróprios.

Neste trabalho, realizado em 2001, foi observado que $85,2 \%$ dos universitários utilizam o filtro solar. Um estudo de 1994-1995 demonstrou que 36,9\% deles usavam filtro solar, numa população com a média de idade de 20 anos. ${ }^{4}$ Foi verificado um aumento na utilização do filtro solar de 1994-1995 para 2001 em populações com médias de idade semelhantes. such as hat (55.9\%), shirt (45.4\%) and beach umbrella (85.5\%) (Chart 3).

\section{DISCUSSION}

In the present work, the university students were questioned regarding their solar exposure and the frequency with which they use sunscreen. The results, in terms of duration of exposure and use of physical means of solar protection, are similar to data in the literature. , $, 10,12,28^{2}$

Seventy percent of the students exposed themselves to the sun during the period of least risk, after 15:00. However, $43.7 \%$ of the students also subjected themselves to the period of greatest ultraviolet radiation intensity, between 10:00 and 15:00. The literature justifies this behavior, during the summer, on the grounds of social factors, such as eating a late lunch; more outdoor sports; and to take maximum advantage of holidays. ${ }^{4}$ Thus, outdoor activities tend to take place mainly during inappropriate times, in relation to the sun.

This work was undertaken in 2001, and found that $85.2 \%$ of the university students use sunscreen. A study from 1994 to 1995 demonstrated that 36.9\% used sunscreen, in a population with a mean age of 20 years. ${ }^{4}$ Thus an increase was verified in the use of sunscreen from 19941995 to 2001 in populations with a similar mean age. 
Sessenta e um por cento dos pesquisados usam fator de proteção solar (FPS) menor do que 15, o que não é preconizado pelas campanhas de prevenção do câncer de pele. Apenas $17,9 \%$ dos estudantes usam filtro solar durante todas as estações do ano, sugerindo que esse hábito parece estar associado à falsa concepção de que o sol só é intenso no verão. Observou-se que, dos universitários que afirmavam ter o costume de usar filtro solar $(85,2 \%)$, apenas $35 \%$ o fazem durante a prática de esportes ao ar livre. Sendo assim, o filtro solar aparentemente só é lembrado e aplicado por eles quando têm a intenção de "bronzear-se".

Neste estudo, foi verificado que independente do uso ou não do filtro solar, a maioria dos estudantes não utiliza outros meios físicos de fotoproteção, como camiseta, chapéu e guarda-sol. A proteção solar efetiva, que consiste no uso de filtro solar, meios físicos de proteção e estratégias para evitar o sol, não é habitualmente praticada. ${ }^{10}$ Mesmo sob o emprego da maneira mais corriqueira de proteção uso do filtro solar -, observa-se um comportamento de risco para os efeitos maléficos do sol.

A maioria dos estudantes que não usam o filtro solar é homem e menor de 25 anos. A literatura mostra que os indivíduos do sexo feminino usam protetor solar com mais freqüência. ${ }^{21} \mathrm{~A}$ partir desses dados, poderíamos levantar a hipótese de que, pelo fato de a maioria das mulheres ser mais vaidosa ou preocupada com a estética, cuida-se melhor ou evita mais do que os homens os efeitos prejudiciais do sol.
Sixty one percent of those that completed the questionnaire use sun protection factor (SPF) less than 15, which is below that recommended by skin cancer prevention campaigns. Only 17.9\% of the students use sunscreen during each of the four seasons, suggesting that this habit seems to be associated with the false conception that the sun is only intense in the summer. It was observed that, of the university students that affirmed they normally use sunscreen $(85.2 \%)$, only $35 \%$ apply it while participating in outdoor sports. Consequently, it appears that sunscreen is only remembered and applied when they intend to "get a tan".

In this study, it was verified that irrespective of the use of sunscreen, most of the students do not use other physical means of solar protection, such as a shirt, hat and beach umbrella. Effective solar protection, consisting of the use of sunscreen together with physical means of protection and strategies to avoid the sun, is not habitually practiced..$^{10}$ Even when using the most common form of solar protection - sunscreen - a risk behavior is observed for the harmful effects of the sun.

Most of the students that do not use sunscreen are male and under 25 years of age. The literature shows that females use suntan lotion with greater frequency. ${ }^{21}$ Based on these data, we could raise the hypothesis that, since most women are more vain or concerned with esthetics, they take better care of themselves and avoid the harmful effects of the sun more than men do.

Quadro 2: Número e percentual de universitários da região metropolitana de Porto Alegre em 2001 segundo os hábitos de fotoproteção / Chart 2: Number and percentage of university students in the metropolitan region of Porto Alegre in 2001, according to use of sunscreen

\begin{tabular}{|c|c|c|c|}
\hline & & $\mathrm{N}$. & $\%$ \\
\hline \multirow[t]{2}{*}{ Uso de filtro solar / Use of sunscreen } & Sim / Yes & 878 & 85.2 \\
\hline & Não / No & 152 & 14.8 \\
\hline \multirow[t]{3}{*}{ Fator de proteção solar / Solar protection factor } & Até oito / Up to 8 & 133 & 15.1 \\
\hline & Entre oito e 15 / 8 to 15 & 407 & 46.4 \\
\hline & Mais de 15 / Over 15 & 338 & 38.5 \\
\hline Uso de filtro solar nas estações do ano & Somente no verão / Only in summer & 721 & 82.1 \\
\hline Use of sunscreen during the seasons of the year & Todas as estações / All seasons & 157 & 17.9 \\
\hline Uso de filtro solar durante a prática de esporte ao ar livre* & $\mathrm{Sim} / \mathrm{Yes}$ & 307 & 35 \\
\hline Use of sunscreen during outdoor sports* & Não / No & 571 & 65 \\
\hline Uso de outros meios físicos** & Chapéu / Hat & 358 & 34.8 \\
\hline \multirow[t]{2}{*}{ Use of other physical protection** } & Camiseta / Shirt & 433 & 42 \\
\hline & Guarda-sol / Beach umbrella & 396 & 38.4 \\
\hline
\end{tabular}

$\mathrm{n}$ : freqüência da amostra / frequency of sample

$\%$ : porcentagem / percentage

*apenas as respostas dos estudantes que afirmam geralmente usar filtro para proteção solar / only the replies of students that affirmed they generally use sunscreen

** alternativas de múltipla escolha / multiple choice alternatives 
Quadro 3: Número e percentual de universitários da região metropolitana de Porto Alegre em 2001 segundo os hábitos dos que não usam filtro solar / Chart 3: Number and percentage of university students in the metropolitan region of Porto Alegre in 2001, according to do not use of sunscreen

Não usam filtro solar / Do not use sunscreen

N.

Masculino / Male

Feminino / Female

Faixa etária / Age group

Até 20 anos / Up to 20 years

De 21 a 25 anos / 21 to 25 years

Mais de 26 anos / Over 26 years
Não usam outros meios físicos para proteção solar*

Do not use other physical means of solar protection*

Chapéu / Hat

Guarda-sol / Beach umbrella

$\mathrm{n}$ : freqüência da amostra / frequency of sample

$\%$ : porcentagem / percentage

* alternativas de múltipla escolha / multiple-choice alternatives

Os dados deste trabalho servem para obter conhecimentos dos hábitos de exposição solar e fotoproteção de uma população universitária da Região Metropolitana de Porto Alegre e, assim, estar mais atentos para orientação desses hábitos nos níveis individual e coletivo.

Os estudos enfatizam a importância da conscientização sobre os perigos da exposição excessiva ao sol, por intermédio da participação da mídia em campanhas de prevenção, ${ }^{4}$ campanhas de orientação nas escolas, ${ }^{13}$ de estratégias para modificar os fatores que interferem na decisão do indivíduo para bronzear-se $\mathrm{e}^{27} \mathrm{e}$ do modelo parental e da educação desde a infância,,${ }^{14}$ bem como a identificação do indivíduo de alto risco para o desenvolvimento de câncer de pele ${ }^{11}$ e da proteção solar efetiva. ${ }^{10}$

\section{CONCLUSÃO}

Neste trabalho, avaliou-se o comportamento dos adultos jovens referente à exposição solar e fotoproteção, e constatou-se que a maioria se expõe excessivamente ao sol, em horários impróprios e sem efetiva proteção solar.

A maioria dos universitários faz uso de filtro solar, porém não o faz durante a prática de esportes ao ar livre. A maioria dos pesquisados não faz uso de outros meios físicos de fotoproteção, como chapéu, camiseta e guarda-sol. Daqueles que não fazem uso de filtro solar, grande parte é de homens com menos de 25 anos.
The data of this work serves to obtain knowledge regarding the solar exposure and sun protection behaviors of a student population in the Metropolitan Region of Porto Alegre and, in this manner, to be more attentive to counseling on an individual and collective level.

Studies have emphasized the importance of a greater awareness regarding the dangers of excessive exposure to the sun, through the participation of the media in prevention campaigns, ${ }^{4}$ school counseling programs, ${ }^{13}$ and other strategies to modify factors involved in the individual's decision to sun bathe $e^{27}$ and of the parental model and education from infancy. ${ }^{14}$ Besides the identification of individuals at high risk of developing skin cancer 11 and effective solar protection. ${ }^{10}$

\section{CONCLUSION}

In this work, the behavior of young adults was evaluated regarding solar exposure and sunscreen and it was verified that most exposed themselves excessively to the sun, at inappropriate times and without resorting to effective solar protection.

The majority of the university students use sunscreen, however not while participating in outdoor sports. Most of those researched do not use any other physical means of solar protection, such as a hat, shirt and beach umbrella. Of those that do not use sunscreen, the great majority are men under 25 years of age. 


\section{REFERÊNCIAS / REFERENCES}

1. Gruijl FR. Skin cancer and solar UV radiation. Eur J Cancer 1999;35(14):2003-9.

2. Hall HI, Miller DR, Rogers JD et al. Update on the incidence and mortality from melanoma in the United States. J Am Acad Dermatol 1999;40(1):35-42.

3. Lim HW, Cooper K. The health impact of solar radiation and prevention strategies. J Am Acad Dermatol 1999;41(1):81-99.

4. Bakos L, Sukster E, Blanco LFO et al. Estudo comparativo sobre o conhecimento e comportamento de adolescentes e adultos frente à exposição solar. An Bras Dermatol 1997;72(3):241-5.

5. Andreassi L, Flori ML, Rubegni P. Role of phototype and skin colour. Adv Exp Med Biol 1999;455:469-75.

6. Garvin T, Eyles J. Public health responses for skin cancer prevention: the policy framing of sun safety in Australia, Canada and England. Soc Sci \& Med 2001;53(9):1175-89.

7. Jackson KM, Aiken LS. A phychosocial model of sun protection and sunbathing in young women. The impact of health beliefs, attitudes, norms, and self-efficacy for sun protection. Health Psychol 2000;19(5):469-78.

8. Lucci A, Citro HW, Wilson L. Assessment of knowledge of melanoma risk factors, prevention, and detection principles in Texas teenagers. J Surg Res 2001;97(2):179-83.

9. Wang SQ, Setlow R, Berwick M et al. Ultraviolet A and melanoma: a review. J Am Acad Dermatol 2001;44(5):837-46.

10. Wright MW, Wright ST, Wagner RF. Mechanisms of sunscreen failure. J Am Acad Dermatol 2001;44(5):781-4.

11. Rigel DS, Carucci JA. Malignant melanoma: prevention, early detection, and treatment in the 21 st century. CA Cancer J Clin 2000;50(4):215-40.

12. Cokkinides VE, Weinstock M, O'Connell MC et al. Sun exposure and sun-protection behaviors and attitudes among U.S. youth, 11 to 18 years of age. Prev Med 2001;33(3):141-51.

13. Kuhl ICP. Fotoproteção na adolescência. An Bras Dermatol 1998;73(supl. 1):38.

14. Marcoux D. Appearance, cosmetics, and body art in adolescents. Dermatol Clin 2000;18(4).

15. Etzel RA, Balk SJ, Bearer CF et al. Ultraviolet light: a danger for children. Pediatrics 1999;104(2):328-33.

16. Pfahlberg A, Kölmel KF, Gefeller O. Timing of excessive ultraviolet radiation and melanoma: epidemiology does not support the existence of a critical period of high susceptibility to solar ultraviolet radiation-induced melanoma. $\mathrm{Br} \mathrm{J}$ Dermatol 2001;144(3):471-5.

17. Rhainds M, Guire L, Claveau J. A population-based survey on the use of artificial tanning devices in the Province of Quebec, Canada. J Am Acad Dermatol 1999;40(4):572-6.

18. Santmyire BR, Feldman SR, Fleischer AB. Lifestyle high-risk behaviors and demographics may predict the level of participation in sun-protection behaviors and skin cancer primary prevention in the United States. Cancer 2001;92(5):1315-24.

19. Coogan PF, Geller ARN, Adams MMS et al. Sun protection practices in preadolescents and adolescents: a school-based survey of almost 25,000 Connecticut schoolchildren. J Am Acad Dermatol 2001;44(3):512-9.

20. Glanz K, Maddock JE, Lew RA et al. A randomized trial of the Hawaii SunSmart program's impact on outdoor recreation staff. J Am Acad Dermatol 2001;44(6):973-8.

21. Banks BA, Silverman RA, Schwartz RH et al. Attitudes of teenagers toward sun exposure and sunscreen use. Pediatrics 1992;89(1):40-2.

22. Diffey B. Has the sun protection factor had its day?. Br Med J 2000;320:176-7.

23. Draelos ZD. A dermatologist's perspective on the final sunscreen monograph. J Am Acad Dermatol 2001;44:109-10.

24. Autier P, Boniol M, Severi G et al. Quantity of sunscreen used by European students. Br J Dermatol 2001;144(2):288-91.

25. Damian DL, Halliday GM, Barnetson RS. Sun protection factor measurement of sunscreens is dependent on minimal erythema dose. Br J Dermatol 1999;141:502-7.

26. Cestari TF. Fotobiologia do melanoma. An Bras Dermatol 1998;73(supl.1):7.

27. Feldman SR, Dempsey JR, Grummer S et al. Implications of a utility model for ultraviolet exposure behavior. J Am Acad Dermatol 2001;45(5):718-22.

28. Michel JL, Magant E et al. Evaluation de la compréhension du risque solaire chez 241 adolescents. Ann Dermatol Venereol 2000;127(4):317-5.

29. Howell JB. The power of prevention. J Am Acad Dermatol 1999;40(4):623-5.

ENDEREÇO PARA CORRESPONDÊNCIA: / MAILING ADDRESS:

Francine Batista Costa

Av. Nilo Peçanba, 2863/603

91330-001 Porto Alegre RS

Tel.: (51) 3328-3271

E-mail:frc.poa@terra.com.br 